\title{
Effects of short term fasting on the evolution of fecal peritonitis in mice ${ }^{1}$
}

\author{
Efeitos de jejum de curta duração na evolução de peritonite fecal em camundongos
}

\author{
Fernando Antônio Martins Bermudes ${ }^{\mathrm{I}}$, Juliano Bertollo Dettoni ${ }^{\mathrm{II}}$, Fausto Edmundo Lima Pereira ${ }^{\mathrm{III}}$ \\ ${ }^{1}$ Research performed at the Unit of Infectious Diseases, Health Sciences Center, Federal University of Espirito Santo (UFES), Brazil. \\ ${ }^{\mathrm{I}}$ Master, Assistant Professor, Department of Surgery, Health Sciences Center, UFES, Brazil. Main author, involved with technical procedures, \\ acquisition and interpretation of data.

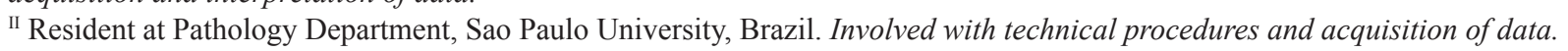 \\ III Full Professor, Department of Pathology and Unit of Infectious Disease, Health Sciences Center, UFES, Brazil. Tutor, responsible for conception and \\ design of the study, analysis and interpretation of data, manuscript writing.
}

\begin{abstract}
Purpose: To investigate the effect of 72 hours food suppression on the evolution of fecal peritonitis in mice evaluating the mortality and measuring the number and size of abscesses formed into the peritoneal cavity. Methods: Mice receiving commercial diet and water ad libitum (control group, $\mathrm{N}=35)$ and mice fasted during $72 \mathrm{~h}(\mathrm{~N}=35)$, receiving only water ad libitum, were inoculated by i.p. route, with $4 \mathrm{uL} / \mathrm{g}$ body weight of a fecal suspension diluted $1: 6$ or $1: 9$ in $0.15 \mathrm{M} \mathrm{NaCl}$ solution (1:6 dilution, 22 controls and 18 fasted; $1: 9$ dilution, 13 controls and 17 fasted). Animals were followed up until two weeks after fecal inoculation, when the survivors were euthanized for evaluation of the number and size of intra-peritoneal abscesses. Mortality was evaluated by Kaplan Meyer curves. Results: Mortality was significantly higher in fasted groups than in controls. However the number and size of abscesses were significantly less in fasted groups than in controls. Conclusion: Seventy two hours food suppression increased the susceptibility to endotoxic shock (high mortality after peritonitis induction) and the resistance to infection with fecal microorganisms (less number and size of intra-peritoneal abscesses). Key words: Fasting. Peritonitis. Shock, Septic. Mice.
\end{abstract}

\section{RESUMO}

Objetivo: Investigar o efeito de jejum de 72 horas na evolução de peritonite fecal em camundongos, avaliando a mortalidade e o número e tamanho dos abscessos formados na cavidade peritoneal. Métodos: Camundongos recebendo dieta ad libitum (grupo controle, $\mathrm{N}=35$ ) e camundongos submetidos a jejum durante $72 \mathrm{~h}(\mathrm{~N}=35)$ foram inoculados, por via intraperitoenal, com $4 \mathrm{uL} / \mathrm{g}$ de peso corporal de uma suspensão de fezes diluída a 1:6 ou 1:9 em NaCl 15M (diluição 1:6, 22 controles e 18 jejum; diluição 1:9, 13 controles e 17 jejum). Os animais foram acompanhados até duas semanas após a inoculação das fezes quando eram eutanaziados para avaliação do número e tamanho dos abscessos intraperitoneais. A mortalidade foi avaliada através das curvas de Kaplan Meyer. Resultados: A mortalidade foi significativamente maior nos animais submetidos ao jejum. No entanto o número e tamanho dos abscessos foram significativamente menores neste grupo. Conclusão: O jejum de 72 horas aumentou a susceptibilidade ao choque endotóxico (maior mortalidade nas primeiras 48 horas) e aumento da resistência aos microorganismos fecais (menor número e tamanho dos abscessos intraperitoneais).

Descritores: Jejum. Peritonite. Choque Séptico. Camundongos. 


\section{Introduction}

Short term feeding suppression is frequent in medical practice. Although the dominant idea is that fasting always enhances infection, human and experimental observations demonstrated that resistance against some infections may be increased during starvation. Murray et al. ${ }^{1}$, studying severe undernutrition in nomadic populations in Africa, reported reduction in severity of infectious diseases especially viral infections, during the periods of acute starvation. This resistance disappeared immediately after re-feeding, when an increasing in susceptibility to infectious agents was observed. These authors did a systematic review of the available literature on the effects of starvation on infections, reporting other similar observations in humans and in both domestic and experimental animals ${ }^{2,3}$.

However, reports on the impact of starvation on the innate or adaptive immune response in humans or experimental animals are scarce and those available present conflicting results. Reduction of cell mediated immunity in $48 \mathrm{~h}$ starved mice infected with Lysteria monocytogense $e^{4}$ or sensitized with oxazolone ${ }^{5,6}$ has been reported. Reduction in plasma levels of leptin occurs during short term fasting in mice and gerbils and it was associated with cell mediated immunosuppression and the increased susceptibility to lipopolyssacharide ${ }^{7-11}$. In humans transient reduction of circulating $\mathrm{T}$ lymphocytes has been reported in patients submitted to fasting with therapeutic proposal ${ }^{12}$. However, either an increased, a reduction or no alterations in $\mathrm{T}$-dependent immune responses has been reported in patients with nervous anorexia ${ }^{13}$.

Regarding the innate immune response, an increased phagocytic and microbicidal activity was reported in mice infected with $L$ monocytogenes after 48 hour fasting ${ }^{14}$. In the other hand increased susceptibility to endotoxin has also been demonstrated in mice after 48 starvation $^{6}$. This increased activity of innate immune response during starvation in mice has been confirmed by demonstration of both augmented activity of NK and NKT cells and increased number of granulocytes and monocytes in bone marrow, in $48 \mathrm{~h}$ starved mice ${ }^{15}$.

Data from the authors cited above demonstrated that fasting hinders cell-mediated immunity but increases microbicidal capacity of macrophages and the sensitivity to endotoxin. It seems that during fasting the macrophages maintain or increases the innate capacity of activation by microbial molecules, producing high level of cytokines as TNF alpha and Il-1, which maintains or increases the macrophage capacity to kill microorganisms but favors endotoxic shock.

The aim of this investigation was to study the effect of a period of 72 hours fasting on the evolution of fecal peritonitis induced by intra-peritoneal injection of stools in mice. In this model of peritonitis there is an acute phase characterized by endotoxic shock, with high mortality, followed by development of intraperitoneal abscesses in survivors. Thus, the effect of starvation on endotoxic shock and on the microbicidal capacity of the peritoneal cavity was assessed by the evaluation of the intensity of shock and by the number and volume of abscesses in survivors.

\section{Methods}

The experiments followed The Council for international Organization of Medical Sciences ethical code for animal experimentation and the principles of the Brazilian College on Animal Experimentation.

Seventy outbreed, Swiss, male mice, 6-8 week old, from the Biological Institute of Espirito Santo State were used in the experiments. In all experiments two paired groups were used: one group (fasted group, $\mathrm{N}=35$ ) submitted to a period of 72 hours fasting receiving water ad libitum (fasted group) and other group (control group, $\mathrm{N}=35$ ) received commercial chow and water ad libitum (control group). Both fasted and control groups, were maintained in cages with anti-coprofhagic floor to avoid coprophagy in the fasted groups.

Fecal peritonitis was induced by intra-peritoneal injection of a suspension of feces collected from the cecum of a donor animal and diluted $1: 6$ or $1: 9$ in $15 \mathrm{M} \mathrm{NaCl}$ solution (1:6 dilution, 22 control and 18 fasted; 1:9 dilution, 13 controls and 17 fasted). Each animal received $4 \mu \mathrm{L} / \mathrm{g}$ body weight of the fecal suspension.

Peritonitis was induced after 72 hours of fasting and the animals were re-feed with the same commercial chow administered to the control group. The same fecal suspension was used to induce the peritonitis in fasted and control groups. The number of animals in each fasted or control group (ten or more by group) is indicated in the results of experiments.

The follow-up was carried out by direct observations of animals every hour interval up to 12 hours after the fecal inoculation and at every 24 hours for a period of two weeks, when all survivors were euthanized to evaluation of the peritoneal abscesses .

Peritoneal abscesses were counted and measured in each animal. For the size each abscess received a score from 1 to 3 : score 1 for abscess with diameter less than $2 \mathrm{~mm}$, score 2 between 2 and $5 \mathrm{~mm}$ and score 3 more than $5 \mathrm{~mm}$. The number of abscesses within a given score was multiplied by the score power and the sum of all results was the final score for the abscesses for each 
animal.

To evaluate the effect of fasting on the lymphoid organs, animals were euthanized in days 0, 3, 6 and 10 days after food suppression. The animals were weighed and euthanized with an intra-peritoneal injection of pentobarbital. The thymus, the spleen and the liver were weighed, fragments were immersed in Bouin fixative and paraffin embedded for histology.

Statistical analysis was done with the SPSS for Windows, version 1.10. Kaplan Meyer curves, with Log Rank test, were used to compare survival between groups. Man-Whitney test was used to compare the number and the scores of abscess. P values less than 0.05 were considered significant.

\section{Results}

Evolution of the animals submitted to 72 hours fasting

All fasted animals in which peritonitis was not induced, a severe weight loss was observed; however a quick recover was noticed after re-feeding (Figure 1A).
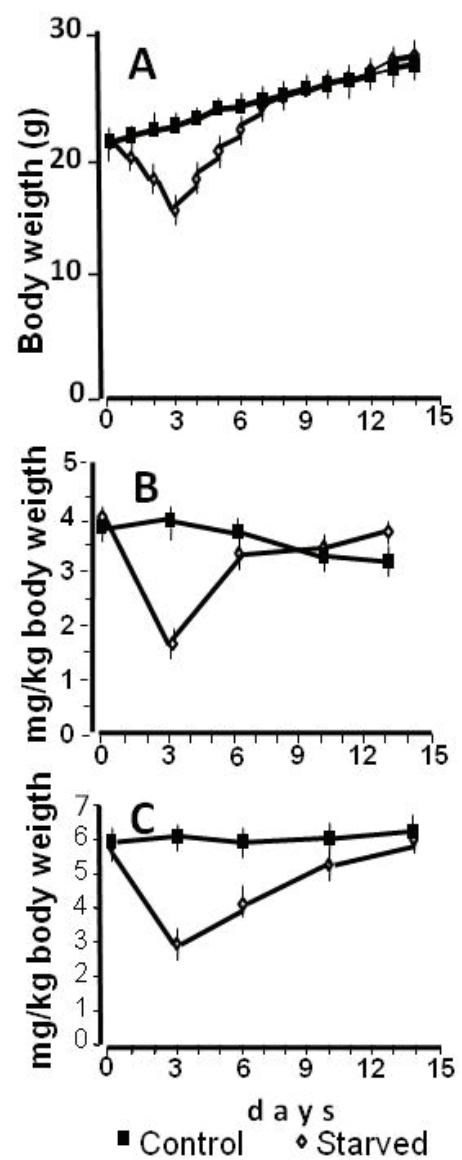

FIGURE 1 - Body (A), thymus (B) and spleen (C) weight in mice starved for $72 \mathrm{~h}$ and than re-fed. Each point represents the mean plus one standard deviation of five animals.
A great weight reduction detected in thymus, spleen and liver, was also reversed up to three days after re-feeding (Figure $1 \mathrm{~B}$ and $\mathrm{C}$ ).

Histological evaluation showed severe depletion of lymphocytes in thymus cortical and in the spleen white pulp.

\section{Evolution of fecal peritonitis}

The mortality observed in fasted and control groups is summarized in Figure 2A (feces 1:6 dilution) and 2D (feces 1:9 dilution).
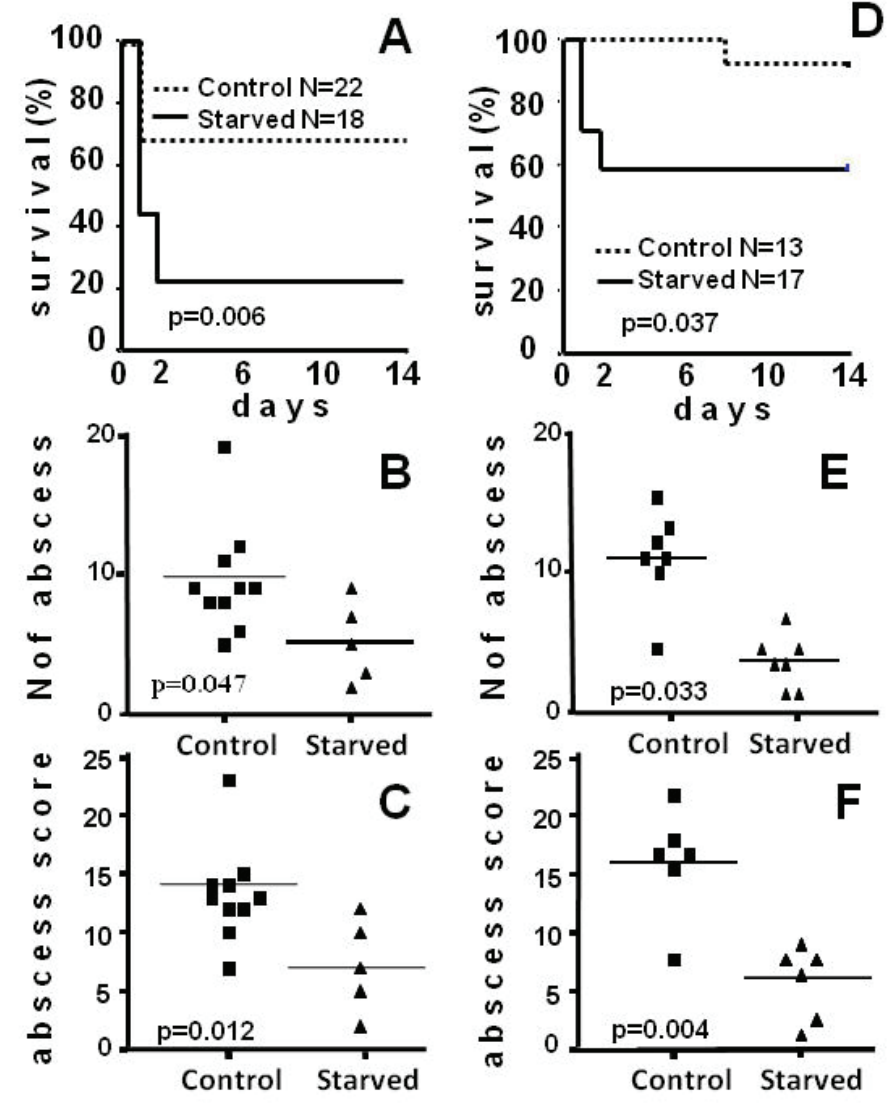

FIGURE 2 - Evolution of peritonitis demonstrated by Kaplan-Meyer survival curves and by number and score of abscesses in survivors, after injection of a fecal suspension 1:6 (A, B and C) or 1:9 (D, E and F) dilution.

After inoculations of feces diluted 1:6 and 1:9, in both fasted and control groups, signals and symptoms of shock (hair bristling, lethargy, hypothermia, diarrhea) occurred earlier and were more severe in the fasted group which presented a significantly higher mortality when compared to the control group, especially in the first 48hours. However, the number of abscesses and its score observed two weeks after peritonitis induction was reduced significantly in fasted animals when compared to the control group regardless of dilution of the inoculated fecal suspension 
(Figure $2 \mathrm{~B}$ and $\mathrm{C}, 1: 6$ dilution; $\mathrm{E}$ and F, 1:9 dilution).

\section{Discussion}

Animals submitted to fasting presented lymphoid tissue and hepatocytes hypotrophy similar to reported in mice submitted to 48hours fasting 9 . The lymphoid tissue hypotrophy was quickly reversed as observed after lymphoid tissue hypotrophy induced by restraint stress in mice ${ }^{16}$. As demonstrated in Figure 1, the recovery of lymphoid tissue in the thymus occurred earlier than in the spleen white pulp.

It is admitted that the observed lymphoid atrophy may be due to the stress induced by starvation, through the activation of hypothalamus-hypophisis-adrenal axis ${ }^{17,18}$. However this mechanism may be more complex, with interference of leptin reduction by the fasting. In fact, leptin administration to starved mice protects from thymus atrophy, reduces both hypothalamushypophisis-adrenal axis activation and plasma levels of corticosterone ${ }^{7}$.

Intra-peritoneal injection of a fecal suspension is a well established model to study endotoxic shock, with high mortality within three days of fecal injection. Inoculation of 4 to $5 \mathrm{uL} / \mathrm{g}$ of body weight of a 1:6 fecal suspension have been used to induce fecal peritonitis with high mortality up to three or four days of fecal injection ${ }^{19}$. However authors that used this model of peritonitis did not follow up the animals after one week and did not report on intra-peritoneal abscesses formation. Here we used a more diluted fecal suspension (1:9 weight/volume) which was able to induce signals of endotoxic shock with less mortality than in experiments with more concentrated inoculums. Our data shows that two weeks after the peritonitis induction, intraperitoneal abscesses were observed in all animals.

Mortality was significantly higher in fasted groups than in controls, especially in the first 48 hours after peritonitis induction. In addition to that, signals of endotoxic shock were more severe in fasted group. These observations confirm that fasting increases the susceptibility to endotoxic shock, as demonstrated after intraperitoneal injection of endotoxin in 48hours starved mice ${ }^{6}$.

The number and size of intra-peritoneal abscesses in survivors were significantly smaller in fasted groups. This observation demonstrates that although the manifestations of endotoxic shock were more severe in fasted animals, they were more resistant to fecal bacteria.

A possible explanation for these results come from recent investigations demonstrating that the adaptive immunity is a regulator of the innate immunity: athymic mice or mice treated with anti-T cells antibodies showed a strong innate immune response, with more severe systemic responses after injection of endotoxin ${ }^{20,21}$. During fasting there is a severe cell mediated immunosuppression ${ }^{8,10}$ that would unleash innate immunity, allowing macrophages to produce more cytokines (therefore increasing the possibility of more severe endotoxic shock) and to have increased microbicidal activity (reduction of peritoneal abscesses). This increased microbicidal activity of peritoneal macrophages was demonstrated in fasted mice infected with Lysteria monocytogenes ${ }^{22}$, which presented increased number of macrophage progenitor cells in bone marrow ${ }^{23}$.

\section{Conclusion}

Seventy two hours fasted mice are more susceptible to endotoxic shock after intra-peritoneal inoculation of feces but showed increased resistance to bacterial infection, as demonstrated by the less number and size of peritoneal abscesses in mice that survive the shock.

\section{References}

1- Murray J, Murray A. Suppression of infection by famine and its activation by refeeding - A Paradox? Persp Biol Med. 1977;20(4):471-83.

2- Murray MJ, Murray AB, Murray MB, Murray CJ. Somali food shelters in the Ogaden famine and their impact on health. Lancet. 1976;1(7972):1283-5.

3- Murray MJ, Murray AB. Starvation suppression and refeeding activation of infection. An ecological necessity? Lancet. 1977;1(8003):123-5.

4- Wing EJ, Magee DM, Barczynski LK. Acute starvation in mice reduces the number of $\mathrm{T}$ cells and suppresses the development of T-cell-mediated immunity. Immunology. 1988;63(4):677-82.

5- Nakamura H, Kouda K, Fan W, Watanabe T, Takeuchi H. Suppressive effects on allergic contact dermatitis by short-term fasting. Toxicol Pathol. 2001;29(2):200-7.

6- Faggioni R, Moser A, Feingold KR, Grunfeld C. Reduced leptin levels in starvation increase susceptibility to endotoxic shock. Am J Pathol. 2000;156(5):1781-7.

7- Ahima RS, Prabakaran D, Mantzoros C, Qu D, Lowell B, MaratosFlier E, Flier JS. Role of leptin in the neuroendocrine response to fasting. Nature. 1996;382(6588):250-2.

8- Lord GM, Matarese G, Howard JK, Baker RJ, Bloom SR, Lechler RI. Leptin modulates the T-cell immune response and reverses starvationinduced immunosuppression. Nature. 1998;394(6696):897-901.

9- Howard JK, Lord GM, Matarese G, Vendetti S, Ghatei MA, Ritter MA, Lechler RI, Bloom SR. Leptin protects mice from starvationinduced lymphoid atrophy and increases thymic cellularity in ob/ob mice. J Clin Invest. 1999;104(8):1051-9.

10- Faggioni R, Feingold KR, Grunfeld C. Leptin regulation of the immune response and the immunodeficiency of malnutrition. FASEB J. 2001;15(15):2565-71.

11- Xu DL, Wang DH. Fasting suppresses T cell-mediated immunity in female Mongolian gerbils (Meriones unguiculatus). Comp Biochem 
Physiol A Mol Integr Physiol. 2010;155(1):25-33.

12- Komaki G, Kanazawa F, Sogawa H, Mine K, Tamai H, Okamura $\mathrm{S}$, Kubo C. Alterations in lymphocyte subsets and pituitaryadrenal gland-related hormones during fasting. Am J Clin Nutr 1997;66(1):147-52.

13- Polack E, Nahmod VE, Emeric-Sauval E, Bello M, Costas M, Finkielman S, Arzt E. Low lymphocyte interferon-gamma production and variable proliferative response in anorexia nervosa patients. J Clin Immunol. 1993;13(6):445-51.

14- Wing EJ, Young JB. Acute starvation protects mice against Listeria monocytogenes. Infect Immun. 1980;28(3):771-6.

15- Shen J, Ren H, Tomiyama-Miyaji C, Watanabe M, Kainuma E, Inoue M, Kuwano Y, Abo T.Resistance and augmentation of innate immunity in mice exposed to starvation. Cell Immunol. 2009;259(1):66-73.

16- Dominguez-Gerpe L, Rey-Mendez M. Time-course of the murine lymphoid tissue involution during and following stressor exposure. Life Sci. 1997;61(10):1019-27.

17- Besedovsky HO, del Rey A. Immune-neuro-endocrine interactions: facts and hypotheses. Endocr Rev. 1996;17(1):64-102.

18- Tarcic N, Ovadia H, Weiss DW, Weidenfeld J. Restraint stressinduced thymic involution and cell apoptosis are dependent on endogenous glucocorticoids. J Neuroimmunol. 1998;82(1):40-6.

19- Shadomy S, Pulaski EJ. Experimental bacterial peritonitis in mice. J Surg Res. 1966;6(3):107-16.

20- Kim KD, Zhao J, Auh S, Yang X, Du P, Tang H, Fu YX. Adaptive immune cells temper initial innate responses. Nat Med. 2007;13(10):1248-52.

21- Zhao J, Yang X, Auh SL, Kim KD, Tang H, Fu YX. Do adaptive immune cells suppress or activate innate immunity? Trends Immunol. 2009;30(1):8-12.

22- Wing EJ, Barczynski LK, Boehmer SM. Effect of acute nutritional deprivation on immune function in mice. I. Macrophages. Immunology. 1983;48(3):543-50.

23- Wing EJ, Barczynski LK, Sherbondy JM. Effect of acute nutritional deprivation on macrophage colony-stimulating factor and macrophage progenitor cells in mice. Infect Immun. 1986;54(1):2459.

\section{Correspondence:}

Conflict of interest: none

Fausto Edmundo Lima Pereira

Núcleo de Doenças Infecciosas CCS, UFES

Av. Marechal Campos, 1468

29040-091 Vitória - ES Brasil

Received: November 16, 2010

felp@ndi.ufes.br

Review: January 12, 2011

Accepted: February 10, 2011 